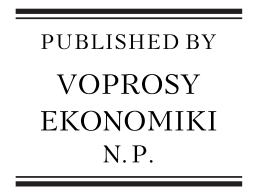

\title{
Factors determining Russia's long-term growth rate
}

\author{
Marek Dabrowski a,b,c,* \\ a HSE University, Moscow, Russia \\ ${ }^{\mathrm{b}}$ Bruegel, Brussels, Belgium \\ ${ }^{\mathrm{c}}$ CASE-Center for Social and Economic Research, Warsaw, Poland
}

\begin{abstract}
In the decade of the 2010s, the pace of economic growth in Russia slowed down to an annual rate of below $2 \%$ and most forecasts suggest that this is will be the new "normal" for the Russian economy at least in the medium-term. While politically and socially disappointing, such a growth slowdown is unavoidable due to adverse demographic trends. A combination of a shrinking working-age population and population aging must lead to a lower growth pace as compared to the period when the working-age population was still increasing and the effects of population aging were limited (the decade of the 2000s). Compensatory measures such as a gradual increase in the retirement age and an open labor migration policy, although economically positive, can only partly mitigate the negative effects of a shrinking domestic labor force. In this respect, Russia does not differ from other European countries and some Asian countries. However, demography and shrinking labor supply cannot fully explain low potential growth. Stagnation in total factor productivity is another reason. It results from a poor business and investment climate, difficulty in diversifying away from the dominant role of the hydrocarbon sector, and deteriorating political and economic relations with the US and EU which limit trade, investment and innovation opportunities. To increase its potential growth, Russia needs comprehensive economic and institutional reforms that, in turn, will be conditioned by political reforms and by improved economic and political relationships with the US, the EU and Russia's neighbors.
\end{abstract}

Keywords: economic growth, neoclassical growth factors, business climate, governance, economic sanctions, geopolitics, macroeconomic policy.

JEL classification: D73, E58, E62, F22, F32, F51, F52, H12, H13, H62, J11.

\section{Introduction}

Since 2012, the Russian economy has stopped growing at its previous rapid pace (with a short but dramatic interruption in 2008 due to the spill-over effects

\footnotetext{
* E-mail address: mdabrowski@hse.ru
} 
of the global financial crisis). Furthermore, between mid-2014 and 2016, Russia suffered from another recession, this time caused by a combination of economic and geopolitical shocks such as the dramatic decline in oil and other commodity prices, and sanctions imposed by the United States (US) and the European Union (EU) following the annexation of Crimea and violent conflict in Donbass, and Russian countersanctions against the US and EU. However, even after oil prices partly rebounded in 2017-2018, growth has never exceeded the annual rate of $2.5 \%$ and most available forecasts suggest that this is a new "normal" for the Russian economy at least in the medium-term.

Such a growth slowdown raises political and social disappointment, on the one hand, and legitimate questions as to whether this is unavoidable, on the other. Our paper ${ }^{1}$ will address the latter question and our answer is partly positive. Yes, due to the dramatic change in demographic trends, the growth slowdown seems to be unavoidable but the scale of this slowdown could be smaller if some key policy choices had been different.

We start our analysis with an overview of growth trends in Russia since 2000 (Section 2). Sections 3 follows a theoretical framework of the neoclassical growth theory. That is, it looks at the dynamics of labor supply, investment and productivity. The next three sections discuss policy choices, which have an impact on productivity trends and, therefore, future growth prospects. Section 4 characterizes the institutional setup, that is, the increasing role of government as owner and regulator, the poor business and investment climate and dysfunctions of the governance system. Section 5 deals with structural characteristics of the Russian economy and trade. Section 6 analyzes the role of geopolitics - that is how choices in the foreign policy sphere influence economic performance and limit economic room for manoeuvre. To make the picture complete, we also look at recent macroeconomic management and try to assess whether monetary and fiscal policies do help economic growth (Section 7). Section 8 presents policy recommendations.

\section{The post-Soviet growth story}

Fig. 1 presents the history of economic growth since 2000 - that is when Russia overcame a deep and almost decade-long transformation-related output decline. The output contraction in the 1990s resulted from structural and institutional distortions that accumulated during several decades of the centrally planned economy, huge macroeconomic disequilibria in the initial period of transition and the slow pace of economic reform in 1990s. In fact, the output decline had already started in the late-Soviet period and was preceded by a near decade of economic stagnation.

Between 1999 and 2008, Russia enjoyed a decade of rapid economic growth facilitated by structural and institutional changes in the 1990s and the global commodity boom (high oil prices). The global financial crisis of 2008-2009 hit

\footnotetext{
This paper draws from an earlier Dabrowski and Mathieu-Collin (2019) paper but it has been substantially revised and updated. Its early draft was presented and discussed at the seminar on "Russian economy at the crossroads: How to boost long-term growth?" co-organized by Bruegel and Delegation of the European Union to the Russian Federation, with the support of the EU-Russia Expert Network on Foreign Policy (EUREN) in Moscow, November 7, 2019.
} 


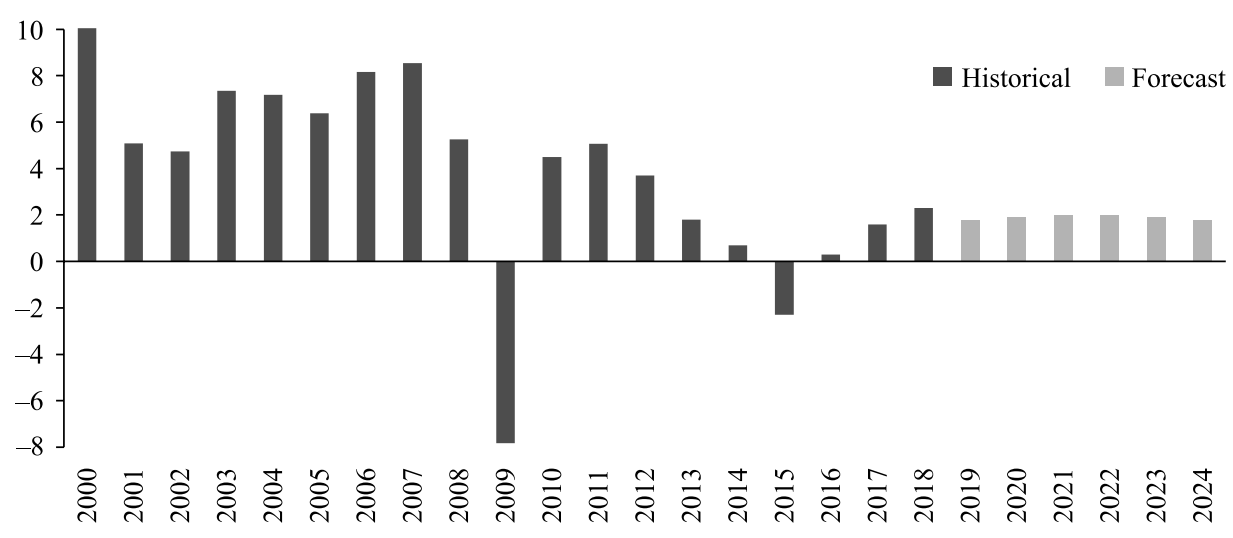

Fig. 1. Russia: Real GDP, annual percentage change, 2000-2018 and IMF forecast for 2019-2024.

Source: IMF World Economic Outlook database, October 2019.

Russia hard, leading to a dramatic GDP decline of $7.8 \%$ in 2009. In the next three years (2010-2012), however, there was a visible recovery. In 2013 the growth rate went below $2 \%$ and the next year Russia was hit by another currency crisis and associated recession (Dabrowski, 2016).

This time, the crisis was not caused by imprudent fiscal and monetary policies, as happened in the late 1980s, the first half of the 1990s and in 1998-1999. Rather it was triggered by the decline in international oil and commodity prices, combined with domestic structural and institutional vulnerabilities. There was also a geopolitical factor: Russia's engagement in the territorial conflict with Ukraine, which resulted in international sanctions against Russia and Russian countersanctions (see Section 6).

The recession started in the third quarter of 2014 and reached its bottom in the second quarter of 2016. Since then, output has recovered, reaching its precrisis level in the second quarter of 2018.

Even if the recession of 2015-2016 was not deep, it was not followed by a strong post-crisis recovery, as happened after the 1998-1999 and 2008-2009 crises. In 2017, growth in real GDP amounted to $1.6 \%$, in 2018 - to $2.3 \%$ and in 2019 it is expected to amount to $1.8 \%$, according to the International Monetary Fund's (IMF) October 2019 World Economic Outlook (WEO) forecasts. Furthermore, according to the same forecast, growth is expected to continue at a rate not exceeding $2 \%$ up to 2024 (see Fig. 1). This is much lower than the growth rate that Russia enjoyed between 1999 and 2008, and looks disappointing for a middle-income country that still has a long way to go to catch up with the high-income group.

Furthermore, if one compares Russia to other emerging-market economies (Fig. 2), its growth performance since 2007 does not look impressive. Brazil, which experienced an even deeper recession in 2014-2016, and Argentina, which has recorded several recession episodes since 2010, are the only exceptions. However, it is fair to say that such a comparison of countries might disregard some important factors, such as different demographic conditions (see Section 3.1 for an analysis of Russia's unfavorable demographic trends) or different stages of economic development (Russia represents the higher level of GDP per capita in PPP terms in the analyzed group). 


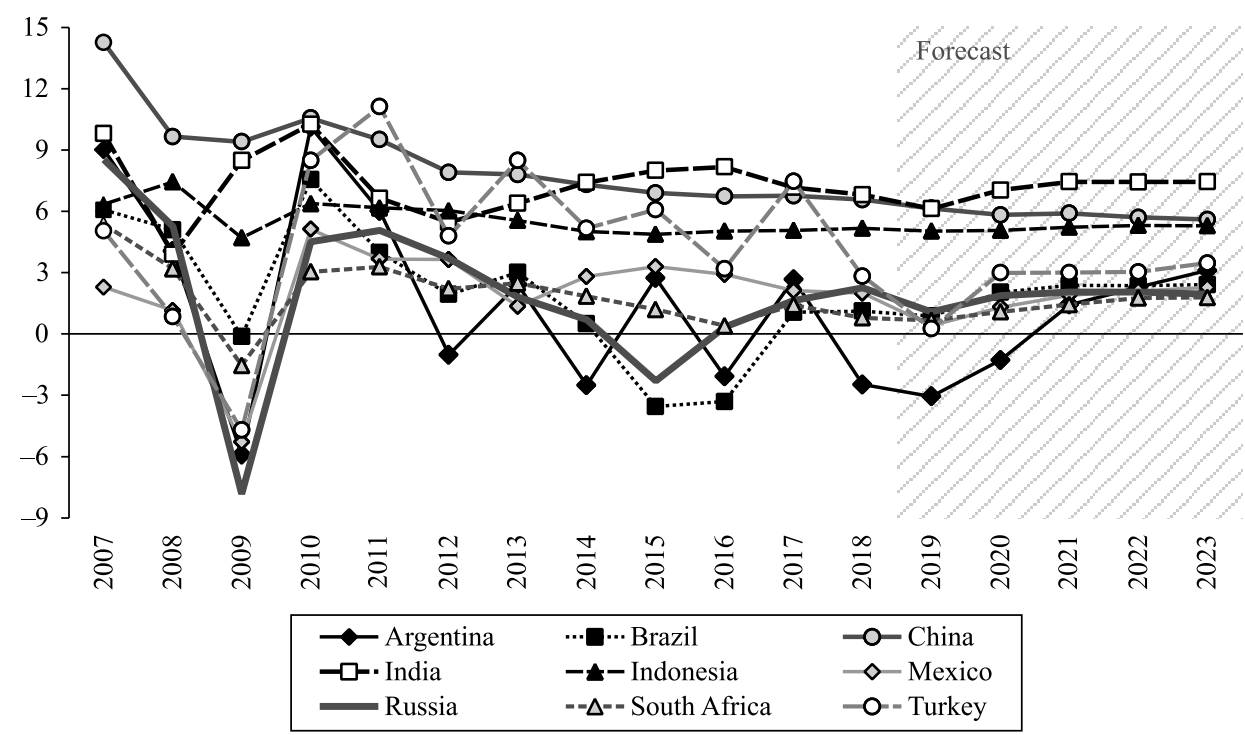

Fig. 2. Real GDP in large emerging-market economies (annual percentage change), 2007-2018 and IMF forecast for 2019-2023.

Source: IMF World Economic Outlook database, October 2019.

Nevertheless, the questions of why the rate of growth of the Russian economy has slowed down and why Russia's growth prospects remain disappointing, require in-depth analysis which will be done in the remaining part of this paper.

\section{Long-term factors of economic growth}

According to the neoclassical growth theory developed by Robert Solow (1956) there are three determinants of economic growth in the long term: labor, capital and technological change, measured by change in total factor productivity (TFP; the so-called Solow residual). In this section, we will analyze each of these factors in the Russian economy.

\subsection{Demographic trends}

The population of Russia has been declining since the early 1990s, while the working-age population started to decline in the 2010s (Vishnevsky and Scherbakova, 2018). Forecasts are even more alarming (Fig. 3). In the next 40 years, the working-age population will shrink by approximately 25 million, that is, by one quarter. In this respect, Russia does not differ from other European and East Asian countries. However, its demographic situation is worse than in other large emerging-market economies except China where the decline in the working-age population will be even more rapid.

For the Russian economy, this adverse demographic trend has two major consequences: (i) reduction of the labor supply; and (ii) population aging.

The shrinking supply of domestic labor must have a negative impact on economic growth, all things being equal. Population aging has a negative impact on the fiscal sustainability of the public pension, healthcare and long-term care sys- 
tems by increasing the old-age dependency ratio. It might also contribute to slower TFP growth as young employees are more dynamic and open to innovation.

Russia tries to counter its shortage of domestic labor by implementing an open-door policy for migrant workers from the countries of the former Soviet Union, especially Tajikistan, Uzbekistan, Kyrgyzstan and Armenia, but also from Moldova, Georgia, Azerbaijan and Ukraine.

In September and October 2018, the Federal Assembly adopted a law on pension reform, under which the retirement age for women was increased from 55 to 60 , and for men from 60 to 65 . The reform will be implemented over a 10-year period, during which, in each calendar year, the retirement age will by increased by half a year. This should help improve the financial balance of the public pension system and will partly mitigate the decreasing supply of labor.

Both measures (open migration policy and increase in retirement age), although helpful to reduce labor shortages, are insufficient to compensate entirely for negative demographic trends due to the scale of this challenge (annual reduction of the working-age population by more than 600,000 people).

The low unemployment rate (below 6\% since 2012) also indicates the lack of unused labor force in the Russian economy (Fig. 4).

The labor shortage means Russia will be unable to return to the rate of growth recorded in the early and mid-2000s when its demographic situation looked better

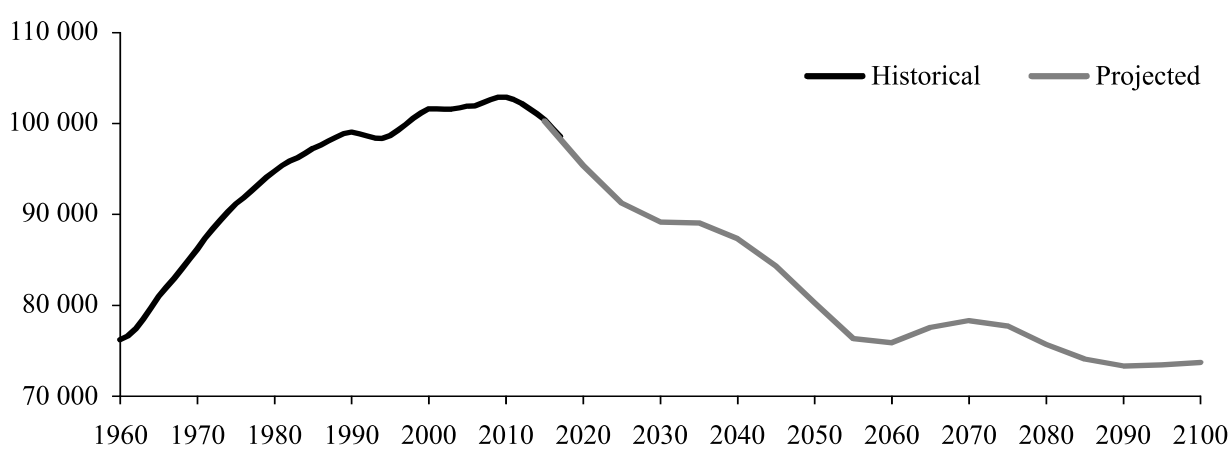

Fig. 3. Population of Russia aged 15-64, 1960-2100 (thousands of people).

Sources: Historical data - World Bank (https://data.worldbank.org/indicator/SP.POP.1564.TO.ZS?locations=RU \&view=chart); projection —United Nations (https://population.un.org/wpp/Download/Standard/Population/).

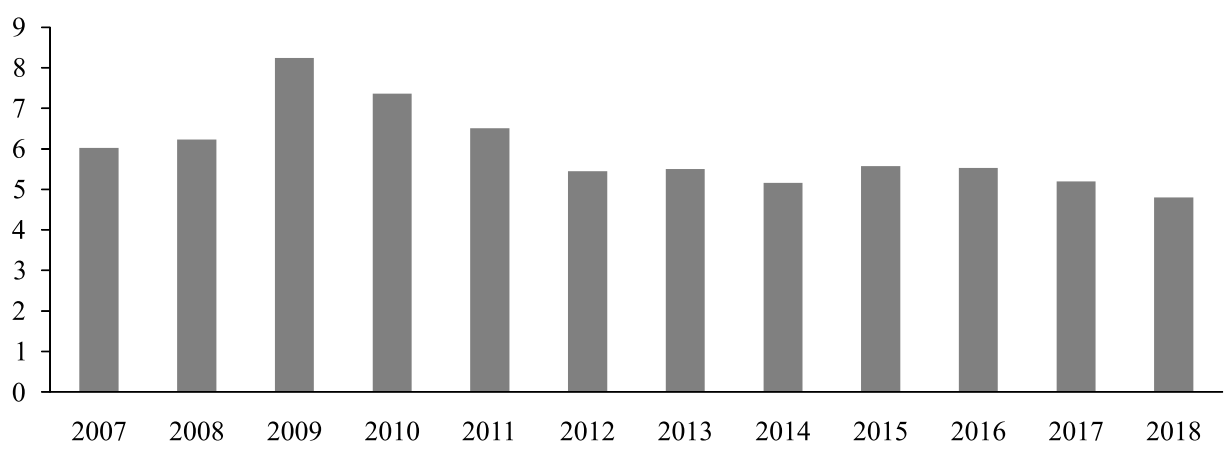

Fig. 4. Russia: Unemployment rate, 2012-2018 (\% of labor force). 
(the working-age population continued to grow, albeit at a slow pace) and there were available labor resources freed by the transition related restructuring in the 1990s.

\subsection{Investment}

Capital investment is the second factor responsible for economic growth. As seen in Fig. 5, total investment rate in Russia, although fluctuating, has a clear tendency to grow.

Its level, well exceeding $20 \%$, places Russia in the middle of the large EMDEs group (Fig. 6). It is lower than in China, India, Indonesia and Turkey but higher compared to Argentina, Brazil and South Africa, and similar to Mexico. Again, given that Russia represents the highest GDP per capita level (in PPP terms) in

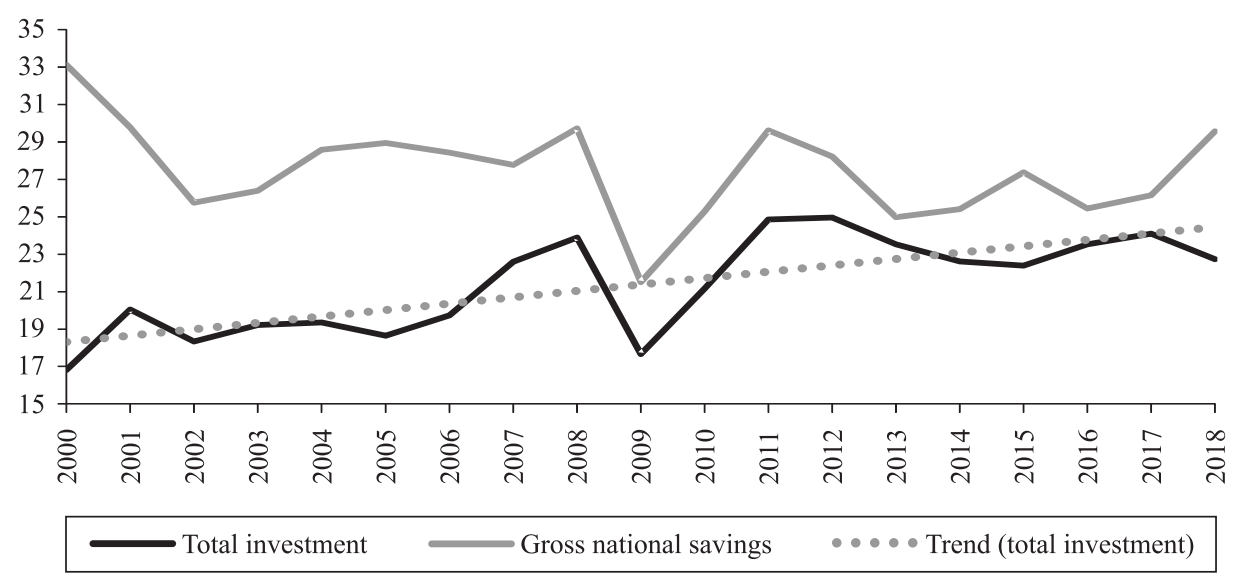

Fig. 5. Russia: Total investment and gross national saving, 2000-2018 (\% of GDP).

Source: IMF World Economic Outlook database, October 2019.

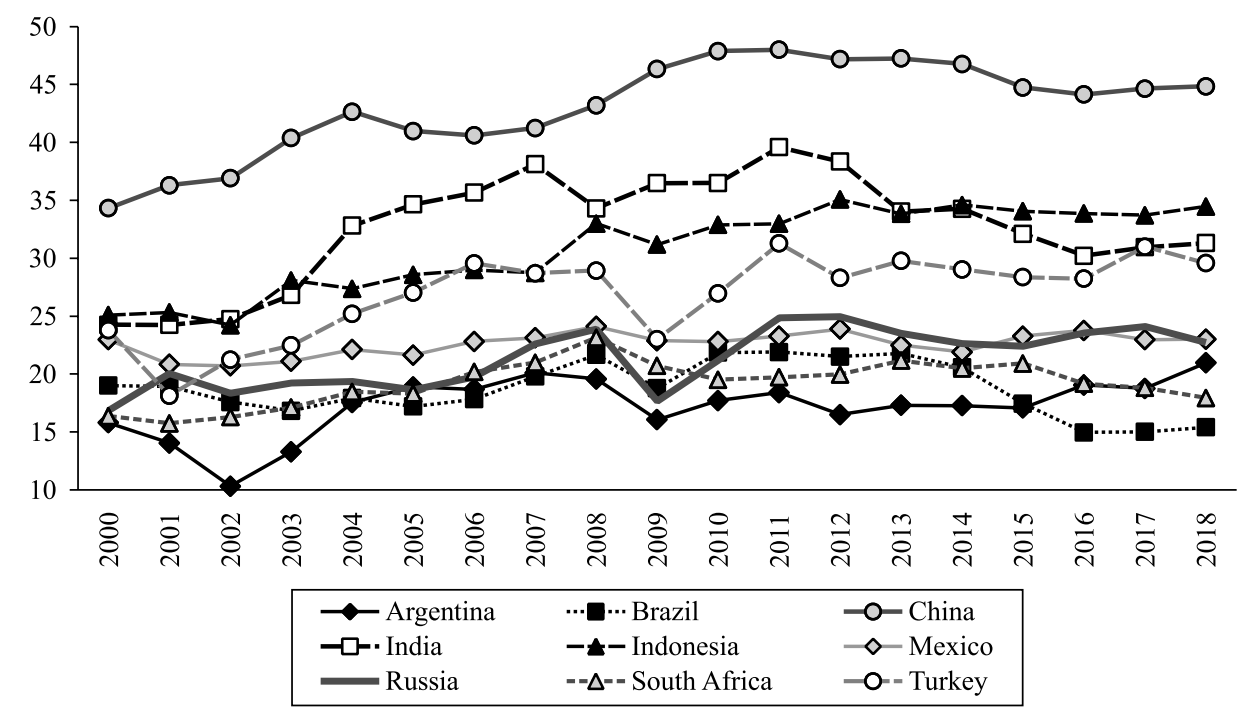

Fig. 6. Total investment in large emerging-market economies, 2000-2018 (\% of GDP).

Source: IMF World Economic Outlook database, October 2019. 


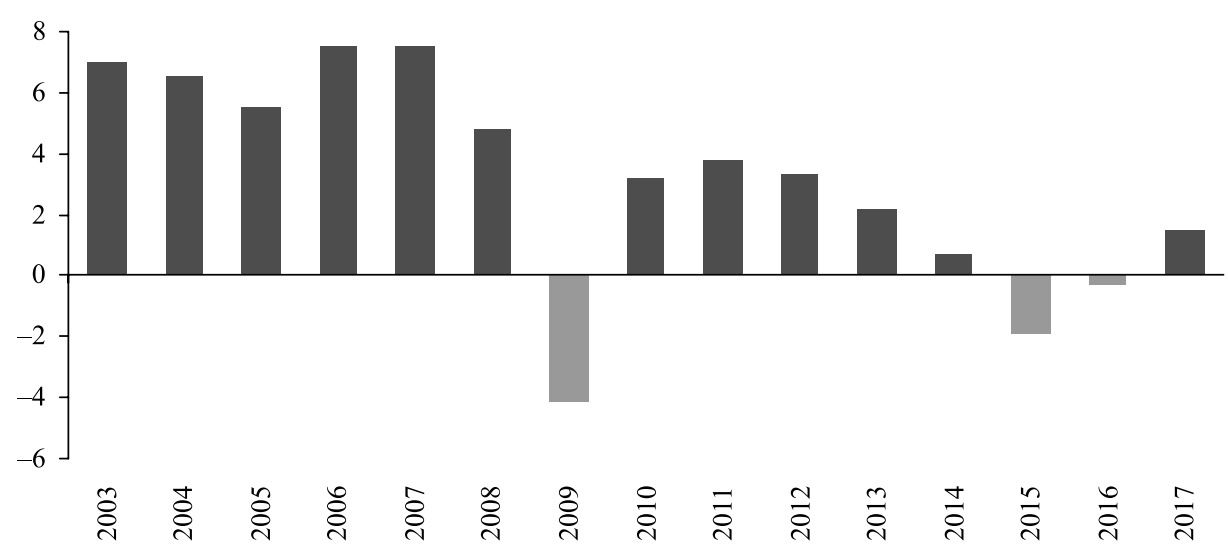

Fig. 7. Russia: Labor productivity (annual percentage change).

Sources: Tradingeconomics.com; Federal State Statistics Service (Rosstat).

the analyzed group, its recent total investment rate does not seem to be too low to generate higher growth rate. In other words, this is not the problem of low volume of investment, which harms the economic growth of Russia, but rather its low effectiveness (see Section 3.3).

Interestingly, the rate of gross national saving in Russia exceeds systematically the rate of investment generating permanent current account surplus. This is partly a result of the presence of substantial oil and gas rent (see Section 5) but it may also suggest a shortage of attractive investment opportunities due to the poor business and investment climate (see Section 4).

\subsection{Productivity}

The deficit of labor resources could be at least partly compensated by an increase in TFP. However, according to Voskoboynikov (2017), TFP and the effectiveness of labor allocation in the Russian economy have deteriorated since the mid-2000s.

This is confirmed by Fig. 7, which demonstrates that growth in labor productivity was relatively fast in the early and mid-2000s when the Russian economy partly benefited from post-transformation reallocation of already existing production factors (see Section 2) but then substantially decelerated to below $2 \%$ annually. In 2009 and 2015-2016, the years of recession, labor productivity declined.

In the subsequent three sections we will look at institutional, structural and policy determinants of the mediocre productivity performance.

\section{Institutional determinants}

One can mention several institutional factors, which negatively influence the competitiveness of the Russian economy and, as result, do not help in TFP growth. In this brief overview we will look at four of them: the increasing share of state ownership in the Russian economy, widespread perception of poor business and investment climate, poor governance, and the insecurity surrounding property rights. 


\subsection{Renationalization of the Russian economy}

After rapid privatization in the 1990s Russia had one of the largest private sectors among post-communist economies. In the early 2000s, the EBRD estimated that the private sector contributed $70 \%$ of GDP. ${ }^{2}$

The turning point came in 2003 with a crackdown on the largest Russian private company, Yukos: its assets were subsequently taken over by the state-owned Rosneft. As a result, the private sector share of GDP decreased from 70 to $65 \%$ between 2004 and $2005 .{ }^{3}$ In the following years, the renationalization trend continued, partly intentionally, in a planned way, and partly as a side-effect of bailing out the troubled companies and banks, especially in the periods of 2008-2009 and 2014-2016 crises. As a result, the share of state-owned enterprises (SOEs) in GDP increased by more than 10 percentage points between 2007 and 2011 (Fig. 8). Some decrease in 2015-2016 can be attributed to lower oil and gas prices.

Fig. 8 also presents the contribution of other components of the public sector to GDP - general government (GG) and state unitary enterprises (SUEs). The share of the former increased as a result of the 2008-2009 crisis but then stayed stable at the level of around 19\% of GDP. This is not high, by comparison with other countries, especially advanced economies. The role of SUEs in generating GDP is marginal and declining.

State ownership dominates in sectors and industries considered by authorities as having a "strategic" character. These are (in brackets percentage share of SOEs in total sales of 100 largest corporation in a given sector/industry in 2017): transportation (83\%), energy $(70.9 \%)$, mining (70\%), finance and insurance $(46.8 \%)$, communal services $(31.9 \%)$, machinery and transport equipment (30.9\%), communication, IT and media (22.7\%) (GIEP, 2018, p. 207).

Di Bella et al. (2019) who extrapolated the EBRD methodological approach confirmed that the share of the state sector in GDP in the second half of the 2000s increased but then stabilized, amounting to $33 \%$ in 2016 . However, its share in the formal sector is higher - close to $40 \%$. Although these estimates are lower

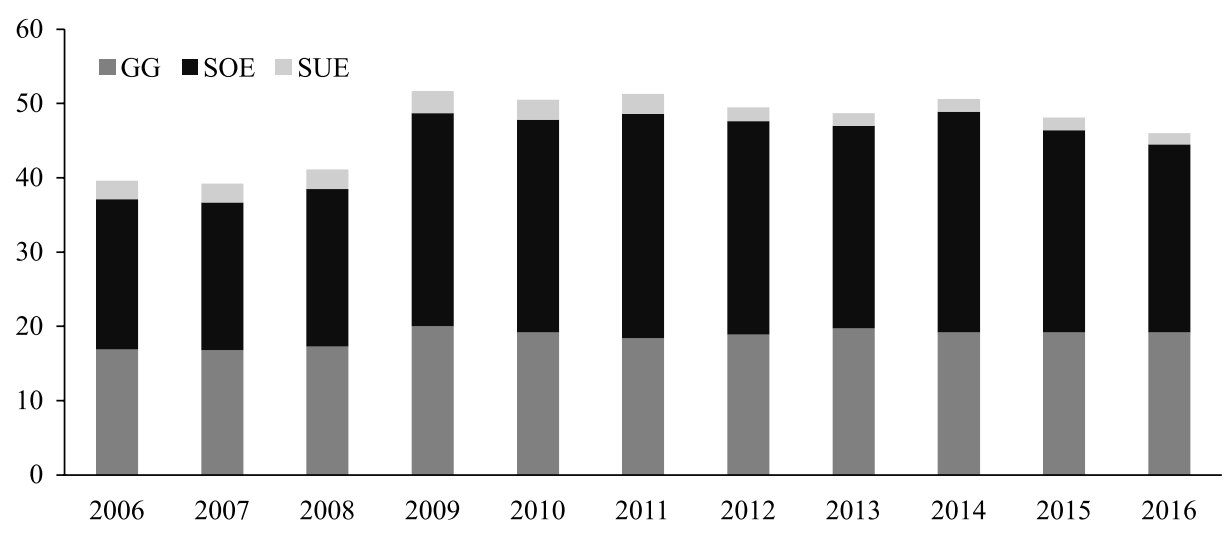

Fig. 8. Russia: Contribution of public sector to GDP, 2006-2016 (\%).

Source: GIEP (2018, p. 214).

\footnotetext{
2 See http://www.ebrd.com/downloads/research/economics/macrodata/sci.xls 3 Ibid.
} 
compared to GIEP (2018), they identify the same sectors and industries of state ownership concentration.

The state-owned enterprises in Russia, similarly to other countries (Boewer, 2017), are less efficient in resource allocation and less dynamic than the private ones (Di Bella et al., 2019). In addition, they are non-transparent, overly politicized and favored by government in its regulatory and procurement activities. Renationalization has resulted, in most cases, in higher concentration in a given sector/industry and its lower competitiveness (Di Bella et al., 2019).

The natural gas monopolist Gazprom might be the best example of the negative consequences of government control. Its gas production in physical volume has stagnated since its formation in the early 1990s, while its business model has remained highly opaque and it often serves Russia's foreign policy goals rather than a purely business strategy with the aim of maximizing profit (see Åslund, 2012).

Several state-owned listed companies were to be privatized, fully or partly, according to the subsequent privatization plans. However, implementation of these plans has been only partial and the degree of their ambition has gradually decreased (GIEP, 2018).

\subsection{Perception of business and investment climate}

Global surveys dealing with various aspects of the business and investment climate provide a contradictory picture of the Russian economy. The World Bank Doing Business (WBDB) 2020 survey, which deals with administrative aspects of business activity in 190 countries, gives Russia a high $28^{\text {th }}$ place in its ranking and a score of 78.2 on the scale from 0 to 100 . Furthermore, Russia's score and position in the ranking have systematically improved, at least since $2013 .{ }^{4}$ Disaggregated scores (Table 1) inform us that Russia performs best in "Getting electricity" (94.00), "Starting a business" (93.04) and "Registering property" (88.74), while scoring worst on "Protecting minority investors" (61.67) and "Resolving insolvency" (58.61).

Two other global surveys - the Heritage Foundation Index of Economic Freedom (HFIEF) and Transparency International Corruption Perception Index

Table 1

Russia: WBDB 2020 ranks and scores.

\begin{tabular}{lll}
\hline Category & Rank & Score \\
\hline Starting a business & 40 & 93.1 \\
Dealing with construction permits & 26 & 78.9 \\
Getting electricity & 7 & 97.5 \\
Registering property & 12 & 88.6 \\
Getting credit & 25 & 80.0 \\
Protecting minority investor & 72 & 60.0 \\
Paying taxes & 58 & 80.5 \\
Trading across borders & 99 & 71.8 \\
Enforcing contracts & 21 & 72.2 \\
Resolving insolvency & 57 & 59.1 \\
Overall & 28 & 78.2 \\
\hline
\end{tabular}

Source: World Bank (https://www.doingbusiness.org/en/data/exploreeconomies/russia\#).

\footnotetext{
4 However, the methodology of the WBDB survey has changed several times, limiting the comparability of WBDB scores and ranking from different years.
} 
Table 2

Russia: 2019 HFIEF scores and rank.

\begin{tabular}{lll}
\hline Categories & 12 economic freedoms & Score \\
\hline Rule of law & Property rights & 52.4 \\
& Judicial effectiveness & 45.1 \\
& Government integrity & 36.6 \\
Government size & Tax burden & 89.4 \\
& Government spending & 62.3 \\
Regulatory efficiency & Fiscal health & 86.6 \\
& Business freedom & 78.4 \\
Open markets & Labor freedom & 52.5 \\
& Monetary freedom & 65.1 \\
Overall score & Trade freedom & 77.8 \\
Ranking & Investment freedom & 30.0 \\
\hline
\end{tabular}

Source: Heritage Index of Economic Freedom 2019 (https://www.heritage.org/index/country/russia).

(TICPI) — offer less optimistic pictures. In the 2019 HFIEF, Russia was ranked $98^{\text {th }}$ out of 180 countries analyzed, with a score of 58.9 (on a scale from 0 to 100), the best result since 2005. ${ }^{5}$ However, this was not enough for it to escape the category of "mostly unfree" countries. HFIEF scored Russia best on "Fiscal health" (86.6), "Tax burden" (89.4) and "Trade freedom" (77.8), and worst on "Investment freedom" (30.0), "Financial freedom" (30.0) and "Government integrity" (36.6) (Table 2).

Finally, according to the TICPI 2018 survey, Russia ranks 138 out of 180 countries, with a score of 28, the same as Guinea, Iran, Lebanon, Mexico and Papua New Guinea. The ranking scores countries from 0 (most corrupt) to 100 (free from corruption). Russia's score has slightly deteriorated as compared to 2017 and previous years.

\subsection{Flawed governance}

The unfavorable business climate has its roots in the failure of political and institutional reforms. Democratization was not completed in the 1990s and then reversed in the 2000s and the 2010s. The 2018 Freedom House Nations in Transit (FHNIT) annual report ${ }^{6}$ assesses the political system in Russia as a "consolidated authoritarian regime" with the overall democracy score of 6.61 on a scale from 1 to 7 , with 1 representing the highest level of democratic progress and 7 the lowest. It is also worth noticing that Russia's score systematically deteriorated in the 2000s and the 2010s.

The overall FHNIT democracy score is an average of ratings in 7 categories: national democratic governance, electoral process, civil society, independent media, local democratic governance, judicial framework and independence, and

\footnotetext{
5 A major improvement was recorded in the 2017 survey with substantial upgrade in the categories of "Property rights" and "Government integrity."

6 See https://freedomhouse.org/report/nations-transit/2018/russia
} 


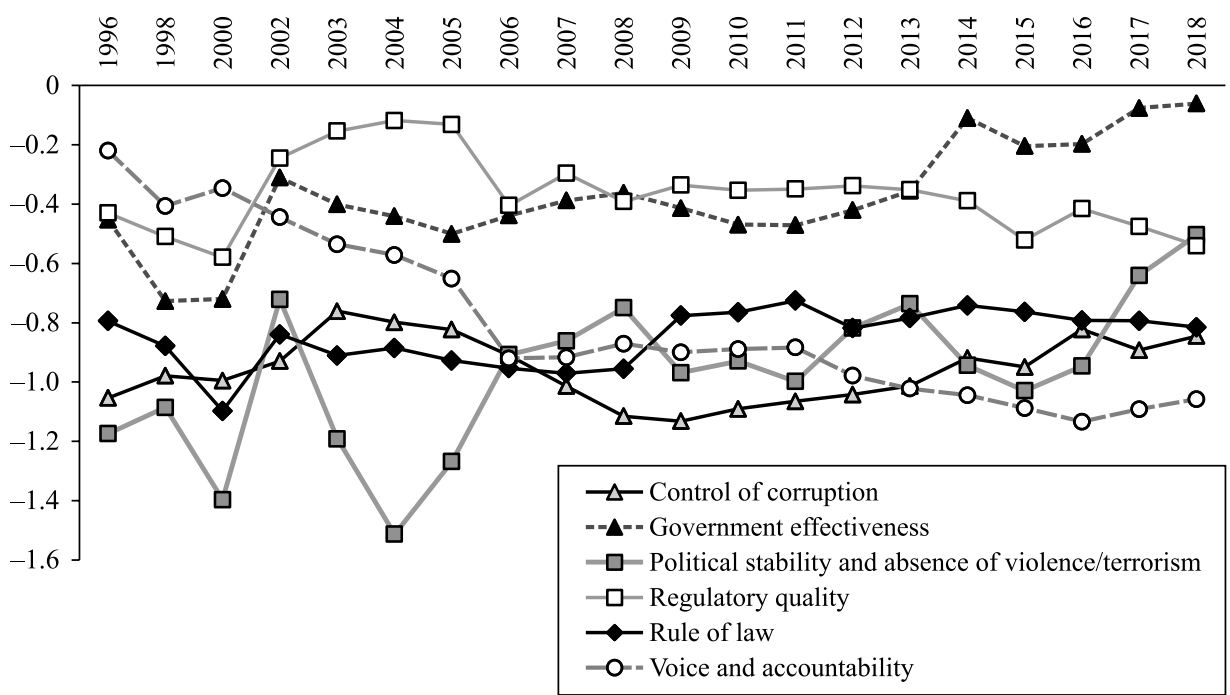

Fig. 9. Russia: World Bank’s Worldwide Governance Indicators, 1996-2018.

Source: World Bank (https://databank.worldbank.org/reports.aspx? source=worldwide-governance-indicators\#).

corruption. There is little difference in sectoral rating, with only slightly better notes given to civil society (6.25).

The World Bank's Worldwide Governance Indicators (WBWGI) also offer an alarming picture. Since the beginning of this rating (1996) Russia has never received a single positive score in any assessed category. ${ }^{7}$ The "Voice and accountability" variable has deteriorated systematically over the entire surveyed period which corresponds with the FHNIT findings. The "Rule of law," "Control of corruption," and "Political stability and absence of violence/ terrorism" remain at a low level (between -0.800 and -1.200 ) even if the last variable somewhat improved since 2015. The two more "technocratic" variables - "Regulatory quality" and "Government effectiveness" look slightly better, however, with the former deteriorating since the mid-2000s and the latter improving in the 2010s.

In practical terms, the above analyzed surveys portray the over-sized and overcentralized (given the federal character of Russia) government apparatus, which continues the old Soviet practices of excessive interference in business activity and the private life of citizens but is unable to provide basic public goods such as security, protection of property rights and civil rights, and basic technical and social infrastructure (see Section 6). The excessive administrative regulations and oppressive Criminal Code allow numerous public security and law enforcement agencies to harass and extort money and assets from private businesses and overuse their extensive powers for private benefit.

\subsection{Insecure property rights}

The practices of state "racketeering" (see Section 4.3), corruption (see Section 4.2) and politically motivated nationalization of business assets (see Section 4.1) undermine the stability of property rights and create business uncer-

7 The WGI survey uses scores ranging from +2.5 (good governance) to -2.5 (poor governance) in each category. 


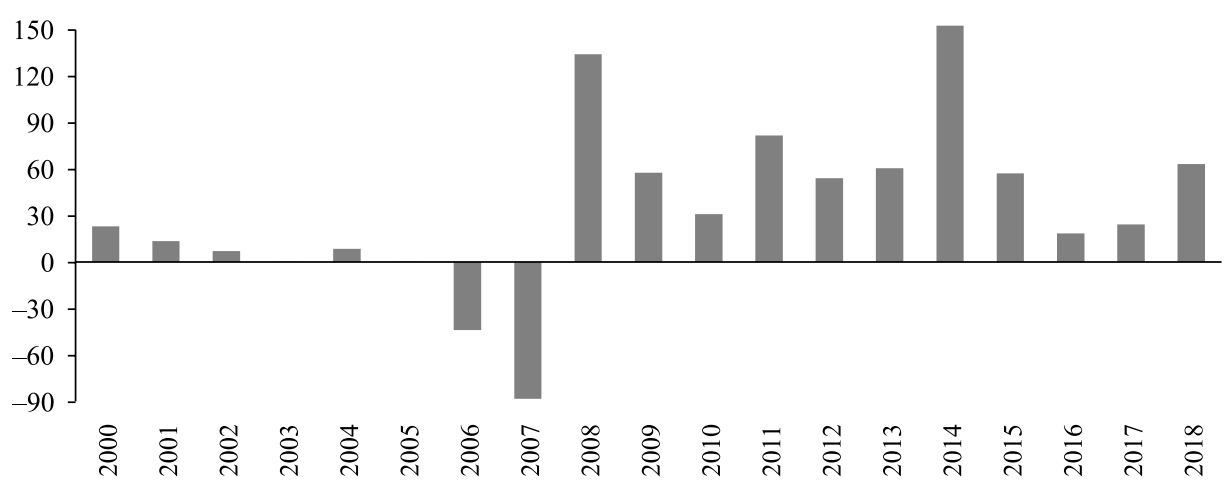

Fig. 10. Russia: Private sector net capital inflows $(-)$ and outflows $(+)$, balance of payments data, 2000-2018 (USD billion).

Source: Bank of Russia (http://www.cbr.ru/vfs/statistics/credit_statistics/bop/outflow.xlsx).

tainty. These are the most negative factors behind the poor business and investment climate in Russia that are not always fully captured by the international surveys (see Section 4.2), in particular, the WBDB.

These fundamental shortcomings in the business environment cannot be compensated by prudent macroeconomic policies (see Section 7), low and relatively simple taxation or several reform measures aimed at simplification in areas including business registration, property registration and court procedures. Russia's continuous net private capital outflows, particularly during the periods of currency crises (Fig. 10), provide further evidence of precarious property rights and personal freedoms in Russia, and of high risks that accompany private business activity.

\section{Structural challenges}

The Russian economy remains dependent on oil and natural gas production and exports. Although in 2013 (that is, before the collapse of oil and gas prices), the share of the hydrocarbon sector in Russian GDP amounted to less than $20 \%$, and both oil and natural gas rents were lower than in several other oil- and gasproducing countries (Figs. 11 and 12), the industries together made up more than $70 \%$ of Russian exports (Fig. 13). They also provided $40-45 \%$ of federal budget revenue.

Obviously, the period of low oil and gas prices (2014-2015) brought these shares down, but since mid-2016, when oil prices started to recover, they have increased again. Furthermore, the drop in oil and gas prices was partly compensated by an increase in their production and in exports, except for 2017 (GIEP, 2018, p. 247) when Russia joined the countries of the Organization of Petroleum Exporting Countries in their effort to limit the oil supply to the global market. Thus, if oil and natural gas prices further recover, the role of hydrocarbon exports and revenue in Russia will become even more important than before the crisis.

Excessive reliance on hydrocarbon production and exports could create a serious economic challenge in the long-term if the development of low-carbon energy sources results in a smaller global demand for oil. 


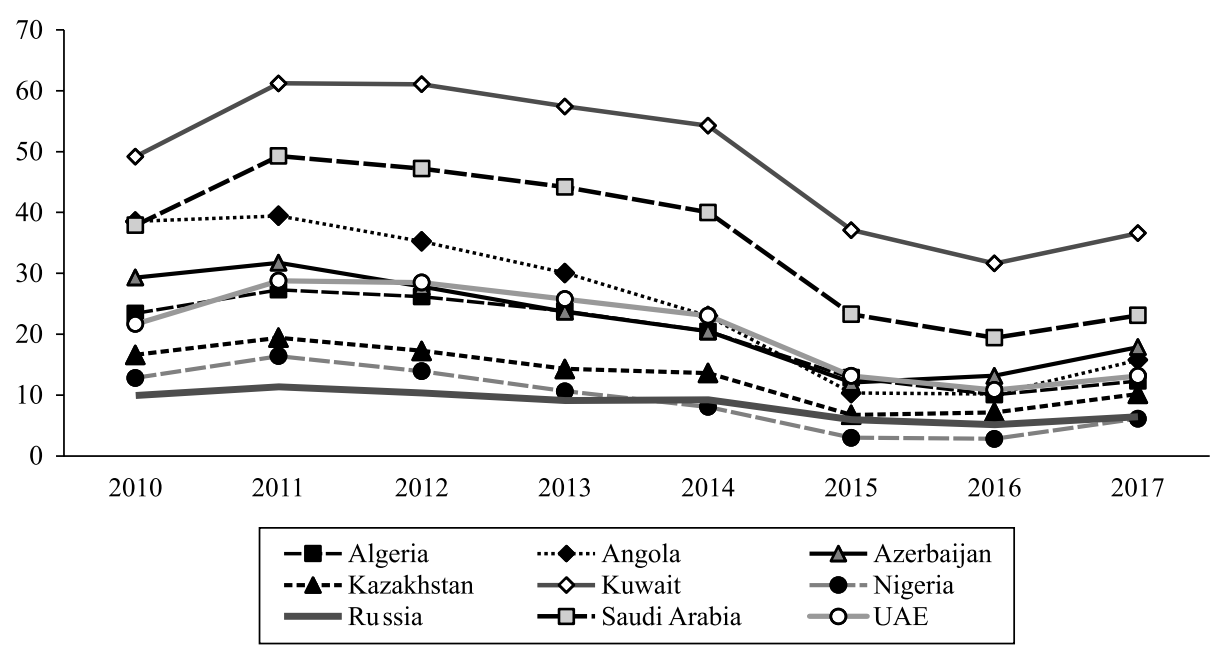

Fig. 11. Oil rent as \% of GDP, various oil-producing countries, 2010-2016.

Source: World Bank World Development Indicators.

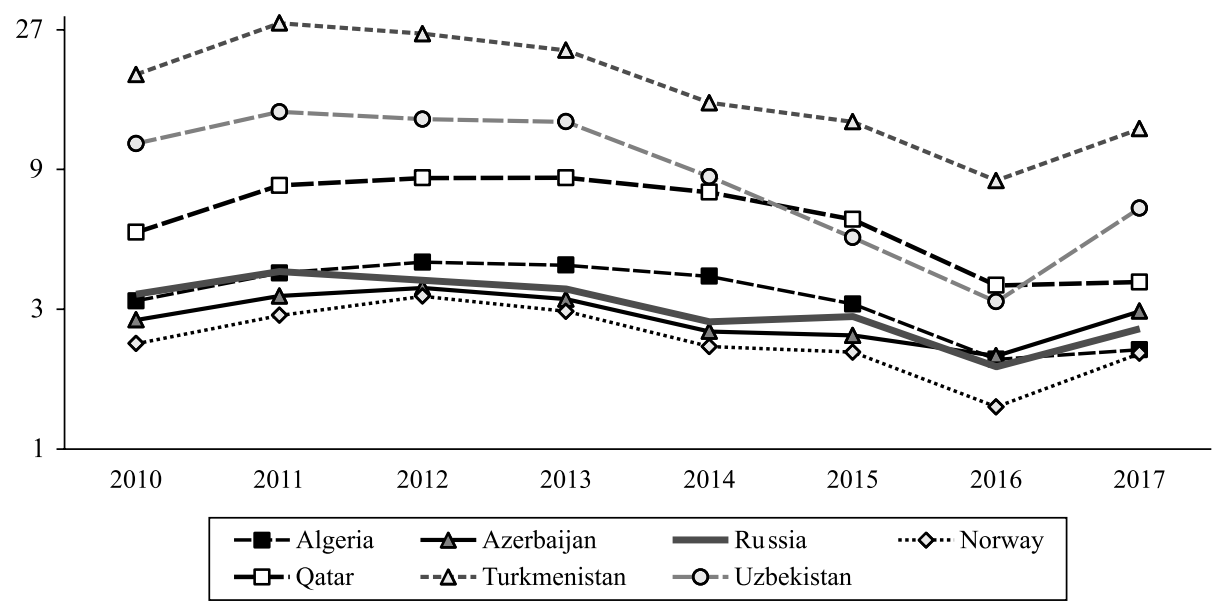

Fig. 12. Natural gas rent as \% of GDP, various gas-producing countries, 2010-2016 (logarithmic scale). Source: World Bank World Development Indicators.

For this and other reasons, the Russian economy requires structural diversification away from the hydrocarbon dominance. Most economists inside and outside Russia accept this. However, in an economy that enjoys unquestionable comparative advantage in production of mineral resources, including hydrocarbons, policies aimed at structural diversification are not easy to conceptualize and implement. The first, macroeconomic obstacle comes from the real exchange rate of the national currency, which appreciates in periods of high hydrocarbon/ commodity prices - the so-called Dutch disease. Since the early 2000s, the Russian authorities have tried to partly neutralize this effect through cumulating oilrelated fiscal surpluses in sovereign wealth funds. A new budgetary rule introduced in 2017, based on an assumed oil price of USD 40 per barrel and capping government expenditure (GIEP, 2018, p. 63), might be helpful in both sterilizing the Dutch disease effect and creating more room for countercyclical fiscal policy. 


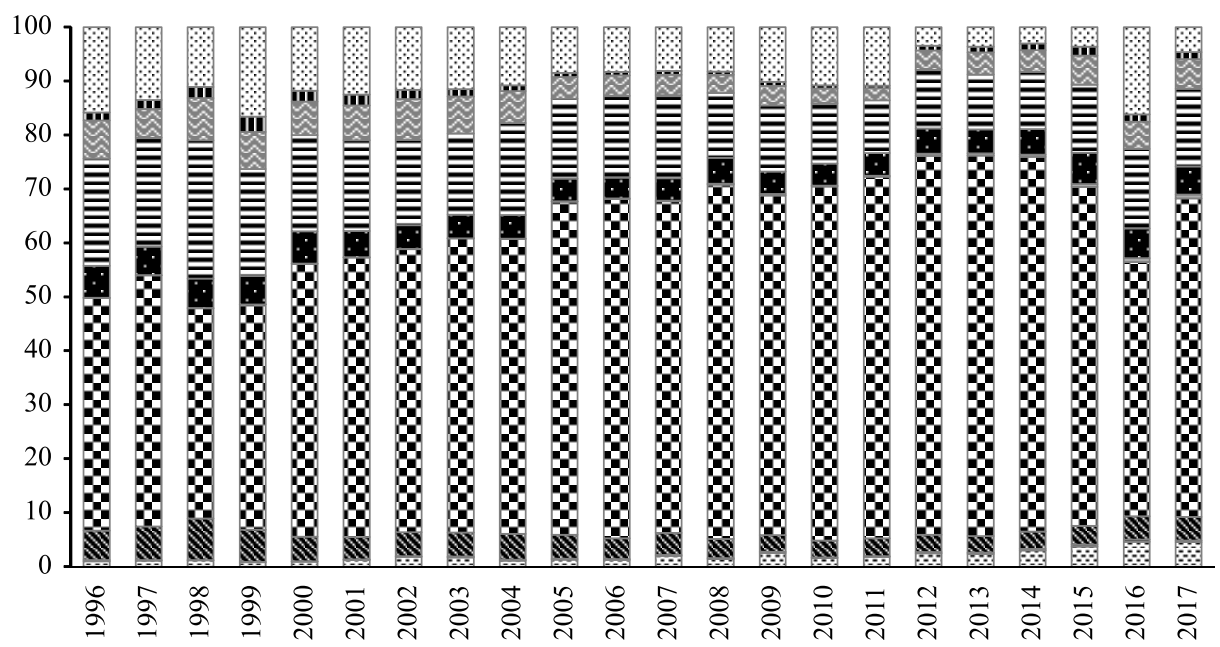

Commodities and transactions not elswhere classif.
III Miscellaneous manufactured articles
Machinery and transport equipment
O Manufactured goods classified chiefly by material
Chemicals and related products, n.e.s.
Animal and vegetable oils, fats and waxes
Mineral fuels, lubricants and related materials
Crude materials, inedible, except fuels
Beverages and tobacco
Food and live animals

Fig. 13. Russia's export profile by product, 1996-2017 (\%).

Source: World Integrated Trade Solution database.

In principle, deep depreciation of the RUR in 2014-2015 should have created room for the expansion of domestic manufacturing industries and other nonoil-dependent activities. Unfortunately, there is little evidence of this happening. Between 2014 and 2017, agriculture, food processing, textiles, cellulose and paper production, the chemical and pharmaceutical industries, and a few others, recorded continuous output growth despite the overall recession (GIEP, 2018, pp. 173-175). However, the entire manufacturing sector was in recession, meaning other industries recorded output losses. The share of what the Russian statistics classifies as "high-technology and science-intensive" sectors in GDP remains unchanged, in the range of $21-22 \%$ since $2013 .{ }^{8}$

There have not been substantial changes in the sectoral structure of Russia's exports (see IMF, 2017a, pp. 4-22), but on the import side (Fig. 14) one can detect two trends: (i) the slowly decreasing share of food products; and (ii) the increasing share of machinery and transport equipment (amounting, in 2017, to $46 \%$ of total imports).

Both trends started to be seen before the 2014-2016 crisis, but ruble (RUR) devaluation and Russian countersanctions (see Section 6) might strengthen import substitution in relation to food products. Import substitution in other areas, for example, industry supplies and investment goods, was only partial and shortlived despite various government incentives and special programs (GIEP, 2018,

8 https://fedstat.ru/indicator/43526 


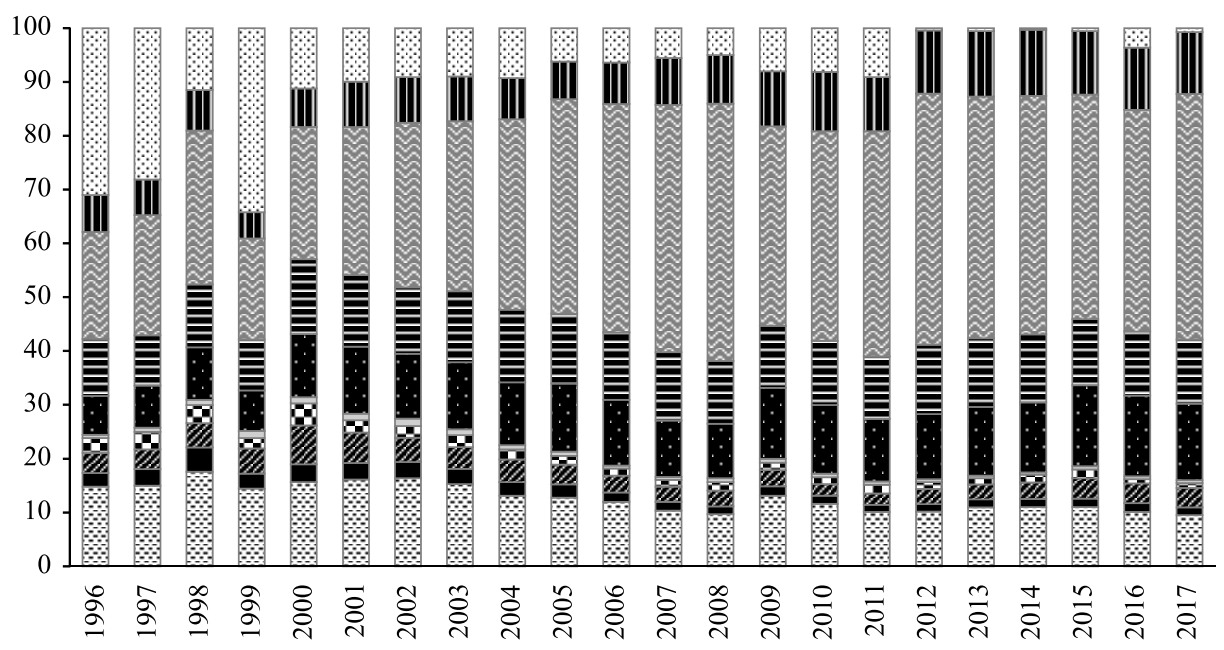

Commodities and transactions not elswhere classif.
II Miscellaneous manufactured articles
Machinery and transport equipment
E Manufactured goods classified chiefly by material
Chemicals and related products, n.e.s.
Animal and vegetable oils, fats and waxes
Mineral fuels, lubricants and related materials
Crude materials, inedible, except fuels
Beverages and tobacco
Food and live animals

Fig. 14. Russia's imports profile by product, 1996-2017 (\%).

Source: World Integrated Trade Solution database.

pp. 186-190), because of the lack of availability of domestic equivalents of imported goods, or the poor quality of domestic equivalents.

Looking ahead, successful structural diversification must rely on market forces, including further opening up to international trade and foreign investment rather than administrative dirigisme, government planning, picking winners and providing state aid to not necessarily economically viable entities. Unfortunately, dirigisme with the aim of promoting import-substitution has been on the rise since 2015 (Connolly and Hanson, 2016). It leads to additional fiscal and quasi-fiscal burdens, trade distortion, state capture by influential special interest groups and political corruption.

Market-oriented diversification requires a supportive macro- and microeconomic environment. Economic agents in non-hydrocarbon and non-commodity sectors must be able to develop and expand their businesses with minimum administrative obstacles, low transaction costs and protection of their property rights. This requires, in turn, improvements in the business climate and governance (see Section 4).

Experience of other emerging-market economies demonstrates that free trade policy can also help in economic diversification and joining global value chains (GVC) in manufacturing by giving domestic producers access to cheap and competitive imports of intermediate and investment goods and giving exporters access to other markets. Unfortunately, Russia joined the WTO relatively late (2012), with long transition periods for various sectors and without choosing 
a full membership menu (for example, Russia is not a part of a WTO Government Procurement Agreement yet). In addition, Russia is party to a small number of free trade agreements, limited mainly to some its post-Soviet neighbors (IMF, 2017a). However, the slow progress in building trade relations with other partners, in particular advanced economies, is partly an effect of geopolitical choices made since the mid-2000s (see Section 6).

\section{Interrelations between geopolitical choices and economic development}

In the second half of the 2000s and the first half of the 2010s political relations between Russia and its Western partners, in the first instance, the US and EU, gradually deteriorated. While the analysis of deep causes and dynamics of this deterioration is beyond the thematic remit of this paper, we would like to draw attention to its negative impact on the economic development of Russia in the short, medium and long term.

Tensions between Russia and its Western partners entered a new stage in March 2014 when Russia annexed Crimea, a part of the Ukrainian territory. Shortly after this annexation, Russia began to actively support the separatist movement in Donbas, which led to Ukrainian authorities losing control over approximately half of this region and the formation of two unrecognized territorial entities - the Donetsk and Luhansk People's Republics. Despite an international effort ${ }^{9}$ to end the conflict in eastern Ukraine (the two Minsk agreements signed on 5 September 2014 and 11 February 2015) it is far from resolved, despite some signs of détente in the second half of 2019. Furthermore, at the end of 2018, the conflict escalated into a new phase caused by Russia's blockade of the Strait of Kerch.

\subsection{Sanctions and countersanctions}

The Ukrainian conflict led to international sanctions against Russia initiated by the US and EU. Canada, Australia, Norway, Iceland, Switzerland, Japan, some of the EU candidate countries and international organizations such as the European Bank for Reconstruction and Development joined, to various degrees, the antiRussian measures. Sanctions were put in place in 2014 and are still in force, subject to regular renewal (in the case of the EU) and updates (concerning the list of sanctioned individuals and companies).

The US and EU sanctions have a multipronged character, ${ }^{10}$ involving four groups of measures (Russell, 2016): political/diplomatic (Tier 1), sanctions against individuals and entities (Tier 2), economic sanctions (Tier 3) and those related to Crimea.

The Tier 1 sanctions involved, non-exhaustively, exclusion of Russia from the G8, suspension of negotiations on Russia's accession to the Organisation for Economic Cooperation and Development and the International Energy Agency, suspension of the semi-annual EU-Russia summits, suspension of negotiations

\footnotetext{
9 The key roles were played by German Chancellor Angela Merkel and French President Francois Hollande.

${ }^{10} \mathrm{See}$ https://www.state.gov/e/eb/tfs/spi/ukrainerussia/ for the list and content of US sanctions and https:// europa.eu/newsroom/highlights/special-coverage/eu-sanctions-against-russia-over-ukraine-crisis_en for the list and content of EU sanctions.
} 
on a new EU-Russia treaty (which could include a free trade agreement) and EU-Russia visa liberalization, suspension of NATO-Russia cooperation, and suspension of the voting rights of the Russian delegation to the Parliamentary Assembly of the Council of Europe (this sanction was terminated in 2019).

The Tier 2 sanctions have been targeted against named individuals and companies, for example those engaged in doing business in Crimea. Measures include visa bans and asset freezes. Some of the affected companies have been supported by Russian public money to compensate for sanction-related losses.

In the economic sphere (Tier 3), sanctions have concentrated on three areas:

- A ban on medium- and long-term financing of the largest state-owned banks and companies;

- A ban on trade in military and dual-use equipment, and in some oil exploration and production equipment and services;

- A ban on trade, including tourism, travel and communication services, with the annexed Crimea, prohibition on the use of Crimean ports and involvement in investment activity in this territory.

In April 2018, the US adopted the Countering America's Adversaries Through Sanctions Act (CAATSA), which partly codified the existing sanctions but also introduced new ones against selected Russian business people and companies, in response to Russia's alleged interference in the US 2016 presidential election. Another wave of US sanctions followed in August 2018, this time in response to the attempted assassination in the United Kingdom of a former Russian intelligence officer.

In August 2014, the Government of the Russian Federation responded to the sanctions with a ban on imports of most food products from countries that adopted sanctions against Russia.

Since 2014, Russia has also started to introduce a series of economic sanctions against Ukraine, the most significant being the revoking of the bilateral free trade agreement (FTA) on 1 January 2016 (in response to the entry into force of the EU-Ukraine FTA). Between November 2015 and June 2016, Russia also adopted a ban on food imports from Turkey and several other economic sanctions against Ankara in response to the downing of a Russian fighter jet by the Turkish air force in the Syria-Turkey border area.

Russia has also extended restrictions on non-resident ownership in some sectors, for example, the media.

\subsection{Economic impact of sanctions and countersanctions: the short-to-medium term}

Assessing the impact on the Russian economy of these sanctions and countersanctions is not an easy task because of the difficulty of disentangling the effects of sanctions and countersanctions from other factors, such as the collapse of the oil price and other commodity prices in mid-2014 (see Korhonen et al., 2018). Furthermore, most of the quantitative assessments were done during the early stage of sanctions implementation (2014-2016) and are based on ex-ante forecasting rather than ex-post analysis. There is a shortage of more recent estimates.

Most available estimates found an annual negative impact ranging from 1 to $2 \%$ of GDP. For example, econometric analysis by Kholodilin and Netsunajev (2016) 
estimated a direct negative impact of sanctions and countersanctions between mid-2014 and the third quarter of 2015. According to their estimate, annualised quarterly growth of real GDP was, on average, lower by 1.98 percentage points compared to the counterfactual scenario (without sanctions). The impact on the euro area's quarterly growth rate was also negative but marginal (in the range of 0.02 percentage points). ${ }^{11}$

Dreger et al. (2016), in their econometric analysis, assessed the impact of sanctions and oil prices on RUR depreciation in 2014-2015 and found that the second factor played a decisive role.

$\operatorname{IMF}(2015$, p. 5) estimated the initial negative impact of sanctions at between 1.0 and $1.5 \%$ of Russian GDP, with a long-term cumulative effect of up to $9 \%$ of GDP.

Gurvich and Prilepskiy (2015) estimated the cumulative loss of Russian GDP arising from Western financial sanctions at 6\% of GDP for the period 2014-2017. A similar result (cumulative 6\%) for the period 2014-2018 was obtained by Bloomberg Economics (Doff, 2018).

The World Bank (2016, p. 40) estimated that removing sanctions would increase forecast GDP growth in 2017 by 0.9 percentage points (from $1.1 \%$ to $2 \%$ ) because of the boost to investment and consumer confidence. However, in subsequent years the forecast growth rate would remain unchanged because of other factors, unrelated to sanctions, limiting Russia's growth potential.

Regarding the Russian countersanctions, Volchkova et al. (2018) estimated that they are responsible for average annual loss of 2,000 RUR (about USD 30) per Russian consumer, or $0.00036 \%$ of Russian GDP per capita in 2014 . Russian producers captured $63 \%$ of this amount and non-sanctioned exporters, in particular from Belarus, took $26 \%$. The remaining $10 \%$ constituted a deadweight loss.

None of the available studies measured the potential impact of the 2018 US CAATSA sanctions.

Overall, sanctions and countersanctions aggravated the 2014-2016 currency crisis and the 2015-2016 recession. In 2014-2015, financial sanctions were particularly painful. By suddenly closing off the international financial market to large state-controlled companies such as Rosneft, Novatek and Gazprom, the sanctions forced the Russian authorities, including the CBRF, to rescue them, causing additional diminution of the CBRF's international reserves and depletion of the National Wealth Fund assets. Financial sanctions also triggered large-scale capital outflows from Russia in 2014-2015 (see Fig. 10) and, therefore, added to market panic and the collapse of the RUR exchange rate in December 2014 and early 2015.

\subsection{Beyond sanctions and countersanctions: other costs of the Ukrainian conflict}

As well as sanctions, the Ukrainian conflict has involved other direct and indirect costs for Russia, such as higher military spending (Table 3), human losses, social costs of refugee flows, aid of various kinds to rebel-controlled territories and so on.

\footnotetext{
${ }^{11}$ Such an asymmetry should not be surprising given the much larger size of the EU economy compared to Russia’s.
} 
Table 3

Russia: Government military, education and health expenditure, 2000-2018 (\% of GDP).

\begin{tabular}{llllllllllll}
\hline Expenditure item & 2000 & 2004 & 2008 & 2009 & 2012 & 2013 & 2014 & 2015 & 2016 & 2017 & 2018 \\
\hline Military & 3.3 & 3.3 & 3.1 & 3.9 & 3.7 & 3.8 & 4.1 & 4.9 & 5.5 & 4.2 & 3.9 \\
Health expenditure & 3.0 & 2.8 & 3.1 & 3.5 & 3.1 & 3.2 & 3.2 & 3.1 & 3.0 & - & - \\
Education & 2.9 & 3.5 & 4.1 & - & 3.8 & 3.8 & 4.0 & 3.8 & 3.7 & - & - \\
\hline
\end{tabular}

Source: World Bank World Development Indicators.

Terminating a free trade regime with Ukraine (see Section 6.1), and several ad hoc trade, investment and transportation restrictions initiated by both sides of the conflict also had a negative impact on economic growth in both countries - larger in Ukraine, smaller but still considerable in Russia (given the different size of both economies).

In addition, there have been the substantial costs of the integration of Crimea into the Russian economy. The costliest investment project was the construction of the Crimea Bridge over the Strait of Kerch, between the Kerch Peninsula (part of the Crimean Peninsula) and Taman Peninsula in the Krasnodarsky krai (part of the Russian mainland), which was opened in May 2018. Its length is over 18 kilometres and the total construction cost was in the region of USD 4 billion.

Åslund (2018) estimated the cost to the Russian federal government of administrating Crimea and providing support to occupied Donbas at USD 4 billion or $0.3 \%$ of Russia's GDP, not including the construction costs of the Crimea Bridge.

Military spending is the only component for which internationally comparative statistics exist. Russia's military expenditure is higher than that of other European countries (see Table 3), oscillating between 3.3\% and 3.9\% of GDP in 2000s. It increased in the 2010s, reaching its peak of 5.5\% in 2016 during the Ukrainian and Syrian conflict. After 2016, its share of GDP started to decrease. High military spending crowds out expenditure on other public services, in particular education and health care (see Table 3), negatively contributing to potential economic growth, an argument frequently raised in Russia's economic debate (see for example Kudrin and Sokolov, 2017; Kudrin and Knobel, 2018).

\subsection{Long-term impact of geopolitical confrontation on economic growth}

Financial and sectoral sanctions limit Russia's growth potential by discouraging investment, both domestic and foreign. The negative effects apply not only to directly sanctioned sectors such as the defence and oil industries. Indirectly, the sanctions, counter-sanctions and deteriorating economic and political relationships with the US and EU negatively affect the entire framework of economic, investment and research cooperation with the West.

It is worth remembering that the US and EU are the two of the three largest economic superpowers, major financial and corporate governance centers, and sources of technology and knowledge-transfer so badly needed by Russia in order to continue its economic modernization. The EU also remains the largest trade and investment partner of Russia, even if the role of China increased substantially since 1990s, especially in trade (Garcia-Herrero and $\mathrm{Xu}, 2019$ ). Despite its impressive rise, the Chinese economy cannot yet replace the EU and the US as a source of various modern technologies, know-how, high-tech sophisticated 


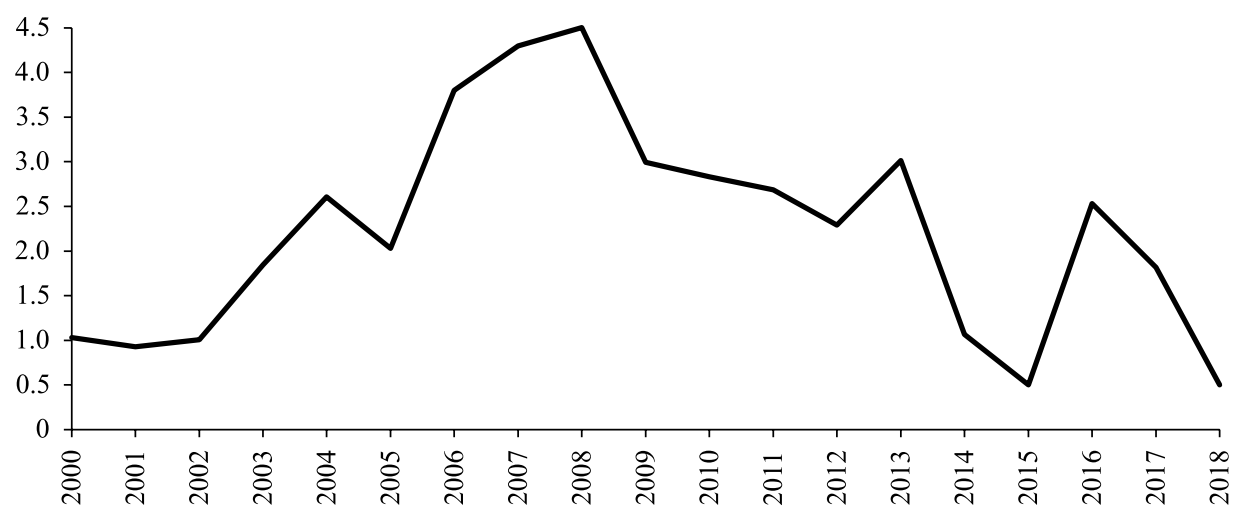

Fig. 15. Russia's FDI, net inflow, 2000-2018 (\% of GDP).

Source: World Bank World Development Indicators.

machinery and equipment, and specialized services; it can play a role of complementary trade and investment partner rather than substituting the most advanced Western economies.

On the domestic economic front, sanctions and counter-sanctions have strengthened protectionism and economic nationalism. For example, the ban on food imports from the EU, US and other countries introduced in August 2014 (see Section 6.1) was, in fact, implementation of much earlier proposals of an agriculture lobby for stronger protection against imports, justified on the grounds of the country's food security (Korhonen et al., 2018). The same can be said about numerous government import-substitution programs launched since 2015 (Connolly and Hanson, 2016). They have led to additional fiscal and quasi-fiscal burdens, trade distortion, state capture by influential special interest groups and political corruption - and often they have contradicted Russia's commitments at the WTO.

Among various restrictive measures, Russia has extended limitations on nonresident ownership in some sectors - for example, the media and industries that may be important for national defence and security ${ }^{12}$ — and access of foreign firms to public procurement - for example of medical equipment. In 2019, the Federal Assembly adopted a law that aims to create a separate "Russian internet" (Runet). The atmosphere of confrontation with the West additionally increases the already strong role of military and security agencies, and limits civil and economic liberties (see Section 4.3).

All these protectionist trends contribute to the deterioration of the already-poor business and investment climate in Russia (see Section 4).

The effects of numerous barriers to foreign investment and the poor business and investment climate (see Section 4) are illustrated by, among other things, a modest and volatile foreign direct investment (FDI) performance (Fig. 15), especially if one takes into account that a substantial part of Russia's FDI inflows comes from investors from Russia and other post-Soviet countries with origins domiciled offshore.

\footnotetext{
${ }^{12}$ On top of those that existed before 2014 like those related to investment in natural resources and the financial sector, gas supply and transportation via pipelines, medical equipment, telecommunication, etc.
} 


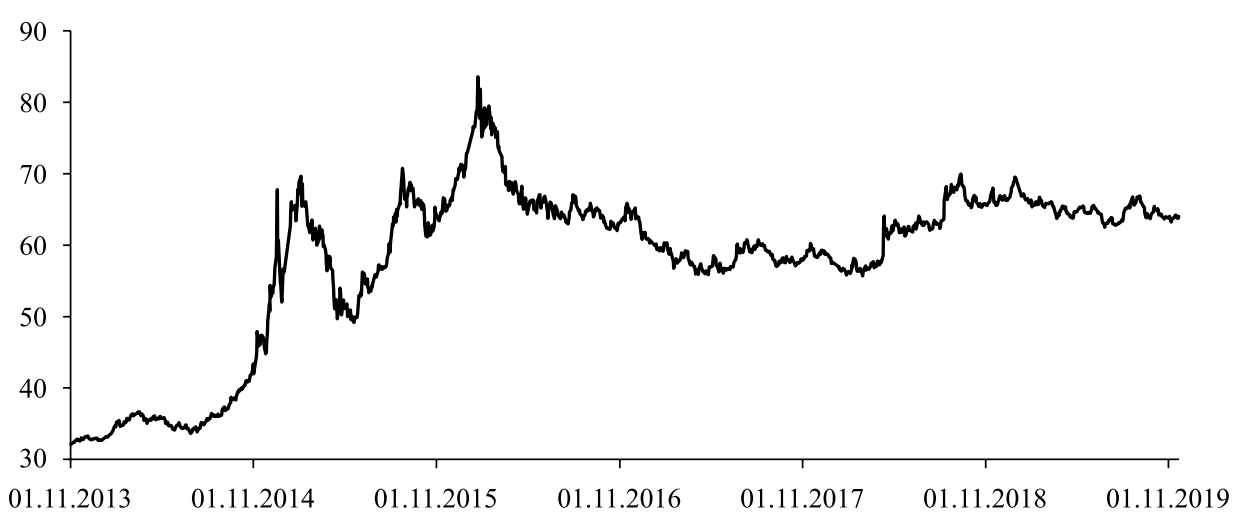

Fig. 16. Ruble exchange rate, 2013-2019 (RUR per 1 USD).

Source: Bank of Russia.

\section{Macroeconomic management}

In the 2010s monetary and fiscal policies have had to deal not only with the growth slowdown but also with yet another currency crisis (2014-2016), the fifth since the early 1990s (Dabrowski, 2016).

As shown in Fig. 16, between December 2013 and December 2015, the RUR depreciated by $55 \%$ against the USD, with depreciation greatest in the period between November 2014 and February 2015. There were then two further but shorter periods of RUR decline — in August 2015 and January-February 2016. After the second quarter of 2016, the RUR gradually strengthened (as a result of the recovery of the oil price) and remained below 60 RUR per 1 USD through most of 2017 and the first quarter of 2018. In April 2018, in response to US sanctions introduced under the CAATSA (see Section 6.1) the RUR depreciated to 61-64 RUR to the USD. It stayed at this level until early August 2018 when it fell again to 66-68 RUR per USD, in reaction to emerging-market turbulence and another wave of US sanctions (see Section 6.2). In the second half of 2019 it returned to the level 63-64 RUR per USD.

The Central Bank of the Russian Federation's (CBRF) international reserves decreased from USD 510 billion at the end of December 2013 to USD 356 billion at the end of April 2015, a drop of more than USD 150 billion. Subsequently, they were gradually rebuilt to a level of about USD 541 billion at the end of October $2019,{ }^{13}$ that is, higher than before the crisis.

The introduction of inflation targeting in Russia and a more flexible exchangerate regime ${ }^{14}$ helped in both macro- and microeconomic adjustment, and limited international reserve losses, even if the timing of the introduction of these measures, at the peak of the crisis, was not optimal (Dabrowski, 2016).

The currency depreciation pushed twelve-month inflation up to $11.4 \%$ in December 2014, 16.9\% in March 2015 and 12.9\% in December 2015 (Fig. 17). Then inflation went down to $5.4 \%$ in December 2016 and 2.5\% in December 2017,

\footnotetext{
${ }^{13} \mathrm{See}$ http://www.cbr.ru/vfs/statistics/credit_statistics/iip_ira/iip_ira_19.xlsx

${ }^{14}$ Given the increasing CBRF's international reserves, the RUR exchange rate cannot be considered as free floating.
} 


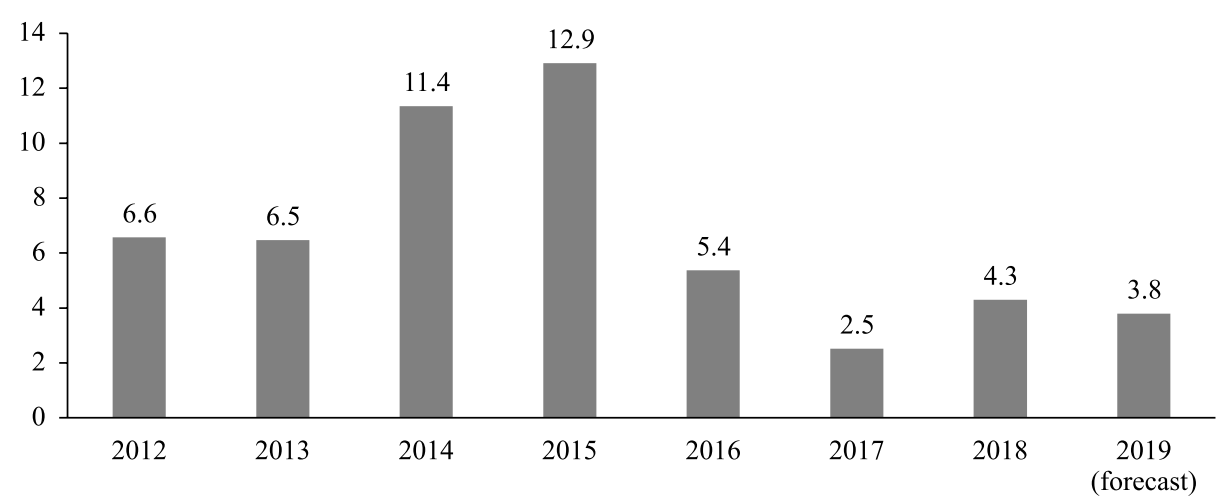

Fig. 17. Inflation, end of period, 2012-2019 (\%).

Source: IMF World Economic Outlook database, October 2019.

the lowest ever level in the history of post-Soviet Russia. The inflation-targeting regime helped in this process. Inflation increased again to $4.3 \%$ in December 2018 but it is expected to go down to $3.8 \%$ in December 2019.

Higher inflation was the main driver of a decline in the level of real disposable income of the population: by $0.2 \%$ in $2014,2.4 \%$ in $2015,4.5 \%$ in 2016 and $0.5 \%$ in 2017 . In 2018 , it increased by $0.1 \% .{ }^{15}$ Declining real wages and other income items (pensions, social benefits, etc.) of the population served as the main adjustment tool on the labor market. Unemployment remained largely unchanged (see Fig. 4).

Fiscal policy remained relatively conservative through the entire crisis period (Fig. 18). In 2015, GG revenue decreased by only 2 percentage points of GDP despite the dramatic collapse of oil and other commodity prices. Again, devaluation of the RUR and the resulting higher inflation helped to compensate partly, in nominal RUR terms, for both the decline in oil prices in dollars and lower real GDP (see Section 2).

Between 2014 and 2016, GG total expenditure increased by only 1.5 percentage points of GDP thanks to limited inflationary indexation of most expenditure items. Since 2016, revenues have started to recover to pre-crisis levels, largely because of higher oil prices. At the same time, expenditure has continued to be kept under control. Nevertheless, the GG balance deteriorated by 4 percentage points of GDP, from a small surplus ( $+0.4 \%$ of GDP) in 2012 to a deficit of $-3.6 \%$ of GDP in 2016. Since 2017, the fiscal situation started to improve and reached surplus both in 2018 and 2019 (see Fig. 18).

Fiscal deficits in the crisis period were financed mainly by running down the assets of the Reserve Fund from USD 91.7 billion on 1 September 2014 to zero on 1 January 2018. ${ }^{16}$ The second sovereign wealth fund - the National Wealth Fund - has suffered less than the Reserve Fund. The volume of its assets fell from USD 87.9 billion on 1 July 2014 to USD 59.7 billion on 1 July 2019, with substantial fluctuations in the meantime (Fig. 19). However, it was substantially rebuilt in the second half of 2019.

\footnotetext{
${ }^{15}$ See https://www.gks.ru/storage/mediabank/urov_12kv-nm(1).doc

${ }^{16}$ See https://www.minfin.ru/common/upload/library/2018/01/main/Obem_sredstv_Rezervnogo_fonda_01_01_ 2018.docx
} 


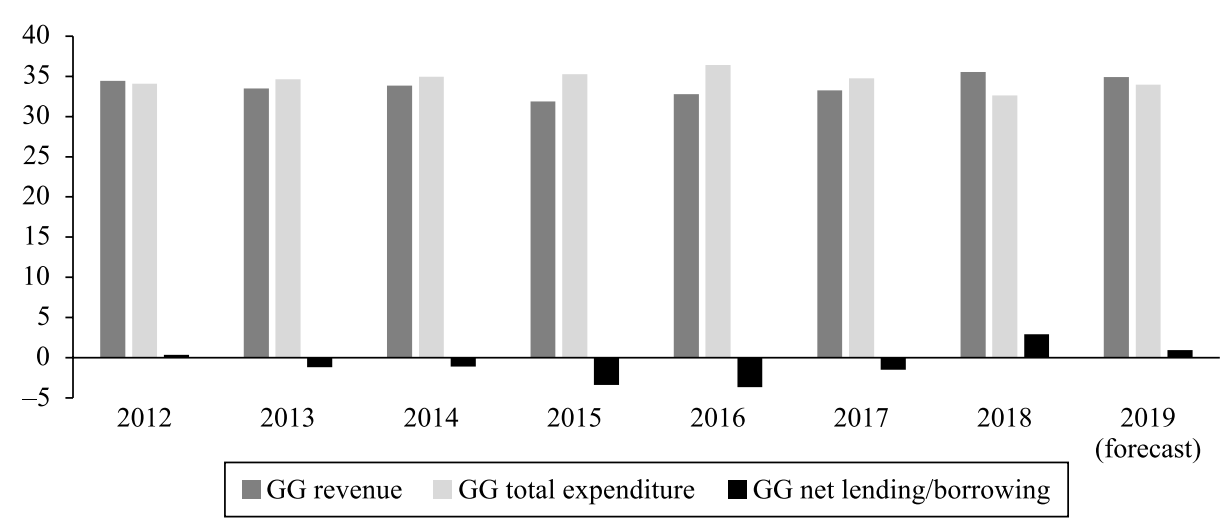

Fig. 18. Russia: GG revenue, total expenditure and net lending/borrowing, 2012-2019 (\% of GDP).

Source: IMF World Economic Outlook database, October 2019.

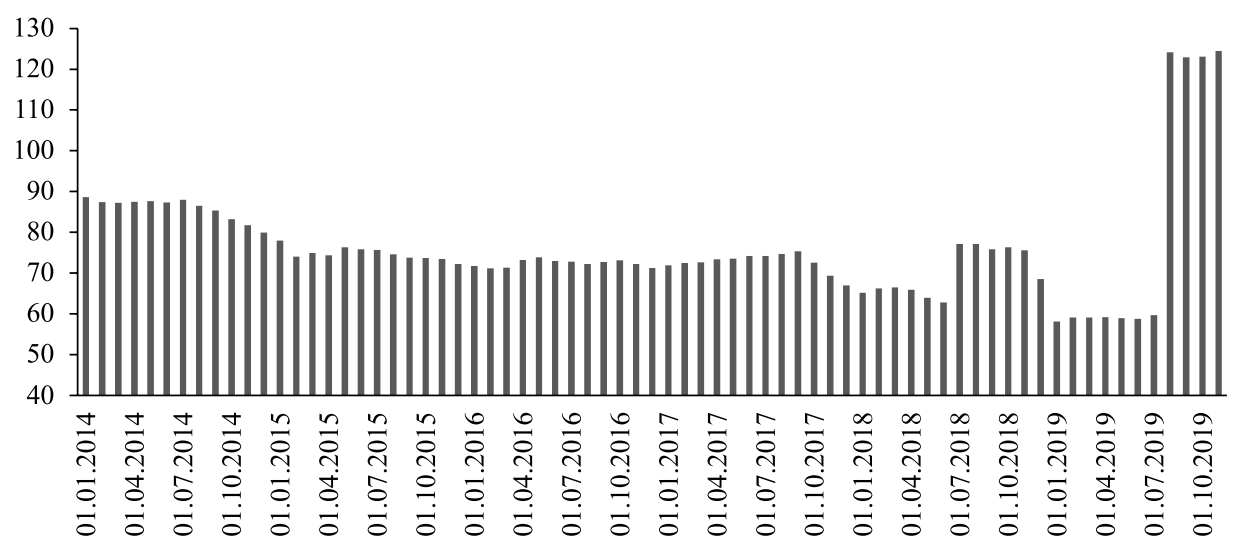

Fig. 19. Russia: National Wealth Fund, 2014-2019 (USD billion).

Source: Ministry of Finance of the Russian Federation (https://www.minfin.ru/common/upload/library/2019/11/ main/Obem_Fonda_natsionalnogo_blagosostoyaniya_01_11_2019.docx).

The remaining part of deficit financing was secured through additional sovereign borrowing, largely on the domestic market, which, however, remains relatively shallow. Opportunities to borrow outside Russia are limited, partly due to the indirect effect of international sanctions (see Section 6).

As a result, GG gross debt increased only marginally, from $13.1 \%$ of GDP in 2013 to $16.4 \%$ in 2015 , and then decreased to $14.4 \%$ in 2018 . It is expected to increase to $16.5 \%$ of GDP in 2019 (Fig. 20). Its level remains low by international standards. The net debt statistics are not provided by the IMF WEO database, but net debt increased as a result of the running down of the Reserve Fund.

Given borrowing constraints and the overall macroeconomic fragility of the Russian economy (see below) prudent fiscal policy and rebuilding fiscal reserves for rainy days seems to be a reasonable policy choice. It helps to stabilize the macroeconomic environment in which Russian enterprises operate.

However, fiscal policy is also a subject of criticism of those (see, e.g., Astrov, 2019) who claim that higher government spending could increase both private consumption and public investment and, as result, push up a growth rate. In our 


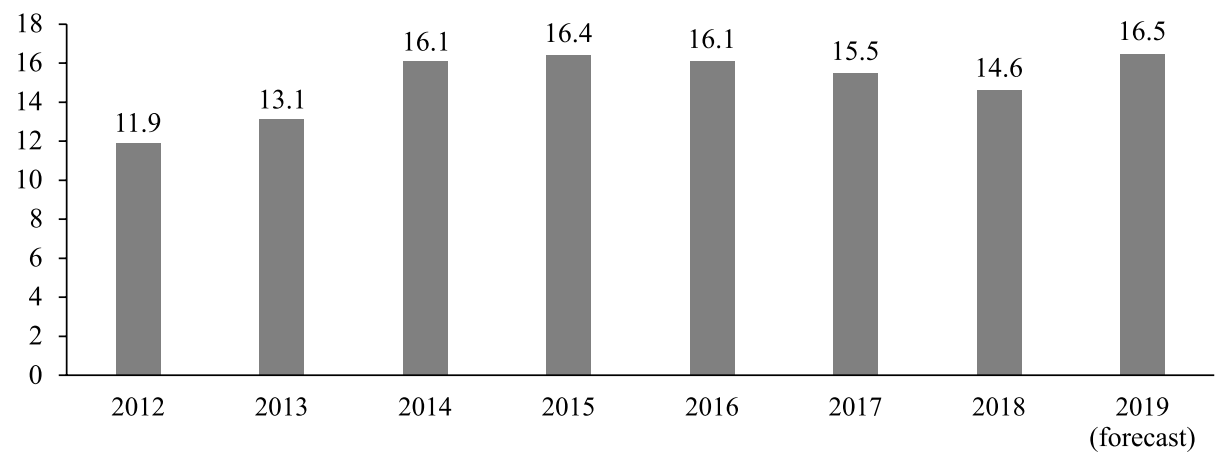

Fig. 20. Russia: GG gross debt, 2012-2019 (\% of GDP).

Source: IMF World Economic Outlook database, October 2019.

opinion, fiscal stimulus could give only a short-term effect because the outlook for medium- and long-term economic growth in Russia is constrained by supplyside factors (see Section 3) rather than insufficient demand.

Overall, macroeconomic management during the crisis can be considered fairly good and prudent from a technocratic point of view. ${ }^{17}$ It tried to minimize the crisis's negative impact on public finances and the real economy and to bring down inflationary expectations. Nevertheless, the crisis itself demonstrated, once again, that macroeconomic stability in Russia remains fragile and vulnerable to various economic and political shocks, despite quite solid fiscal fundamentals and the CBRF's large international reserves. Trust in the ruble and the domestic financial system is limited, which, along with other institutional factors, does not help in improving the business and investment climate (see Section 6).

\section{Conclusions: The way ahead}

This paper's main conclusion is that Russia's economy cannot grow at the pace recorded in the early and mid-2000s because of the different external environment, the different stage of development and serious demographic headwinds. However, it can grow faster than it is currently.

Given the adverse demographic trends facing Russia, boosting TFP is the only way to increase potential growth and return to gradual GDP-per-capita convergence with high-income countries. However, this requires far-reaching institutional and structural reforms that, in turn, depend on political reform.

The IMF (2017b) recommends five areas in which such reforms can be implemented:

- Improving the investment climate, including strengthening property rights and contract enforcement, reduction of burdensome business operating and licensing standards, which discourage foreign investors;

- Investing in infrastructure to improve connectivity, reducing transportation costs and ensuring better access to domestic and foreign markets;

- Creating a more efficient goods market, among others, by simplifying customs procedures;

\footnotetext{
17 The most controversial episode related to operations to rescue the large state-owned corporations cut off from international financial markets by sanctions in the last quarter of 2014.
} 
- Strengthening trade relationships beyond Russia's immediate neighbors;

- Supporting innovation by allocating more resources to research and development. In our opinion, several other measures should be added to this list.

First, Russia needs a new privatization program based on transparent procedures. It should be open to both domestic and foreign investors on equal terms. This would allow reduction of what Di Bella et al. (2019) call "the state's footprint in the economy," the more efficient use of available resources and their higher productivity, an increase in domestic competition, a reduction in the involvement of SOEs in performing non-economic functions (such as non-transparent financing of various political activities) and in political corruption, bringing in more genuine FDI and the inclusion of Russian companies in GVC. Parallel to privatization, some sectors need de-monopolization and internal restructuring. For example, natural gas production could be unbundled from network transmission and retail distribution, similar to what was done in the Russian electricity sector in 2006-2008.

Second, improving the business and investment climate requires far-reaching institutional and political reforms. For example, strengthening property rights and contract enforcement will be impossible without genuine independence of the judiciary. Fighting corruption and business extortion will be impossible without the democratic oversight of public administration, law enforcement and public security agencies, and without media freedom.

Third, deeper integration of Russia in the global economy must go beyond the strengthening of trade relationships in their narrow sense (although this is also important). It requires far-reaching economic and technological partnerships and cooperation with leading advanced economies, including the EU and the US. Furthermore, the future economic development of Russia will depend, to a great degree, on global economic growth and the stability of international commodity and financial markets. In other words, Russia should be an active player in defending the global liberal economic order and in strengthening it through relevant reforms.

Fourth, closer economic and political cooperation with the EU and the US and conflict resolution in its neighborhood would allow Russia to shift part of its budget resources that are currently targeted at military and security spending to infrastructure, education, research and public health programs.

Fifth, political reforms and better guarantees of civil liberties can help increase economic freedom, innovation and business initiative.

Overall, given Russia's increasing labor-supply constraints, the development of innovative business activity and high-value added manufacturing and services is the only realistic long-term strategy that would enable an upper-middle-income economy such as Russia to diversify away from the hydrocarbon monoculture.

\section{References}

Åslund, A. (2012). Why Gazprom resembles a crime syndicate. The Moscow Times, February 27. https://www.themoscowtimes.com/2012/02/27/why-gazprom-resembles-a-crime-syndicate-a12914

Åslund, A. (2018). The toll of Putin's wars. Project Syndicate, 3 September. https://www.projectsyndicate.org/commentary/cost-of-wars-for-russia-by-anders-aslund-2018-09

Astrov, V. (2019). Russia: Self-inflicted stagnation. In Braced for fallout from global slowdown. WIIW Forecast Report (No. Autumn 2019, pp. 105-109). Vienna Institute for International Economic Studies. 
Boewer, U. (2017). State-owned enterprises in emerging Europe: The good, the bad, and the ugly. IMF Working Paper, WP/17/221.

Connolly, R., \& Hanson, P. (2016). Import substitution and economic sovereignty in Russia. Research Paper, Russia and Eurasia Program, Chatham House. Available at https://www. chathamhouse.org/sites/default/files/publications/research/2016-06-09-import-substitutionrussia-connolly-hanson.pdf

Dabrowski, M. (2016). Currency crises in post-Soviet economies - a never ending story? Russian Journal of Economics, 2 (3), 302-326. https://doi.org/10.1016/j.ruje.2016.08.002

Dabrowski, M., \& Mathieu-Collin, A. (2019). Russia's growth problem. Bruegel Policy Contribution, No. 4/2019.

Di Bella, G., Dynnikova, O., \& Slavov, S. (2019). The Russian state's size and its footprint: Have they increased? IMF Working Paper, No. WP/19/53.

Doff, N. (2018). Here's one measure that shows sanctions on Russia are working. Bloomberg, November 16. https://www.bloomberg.com/news/articles/2018-11-16/here-s-one-measure-thatshows-sanctions-on-russia-are-working

Dreger, C., Kholodilin, K. A., Ulbricht D., \& Fidrmuc, J. (2016). Between the hammer and the anvil: The impact of economic sanctions and oil prices on Russia's ruble. Journal of Comparative Economics, 44 (2), 295-308. https://doi.org/10.1016/j.jce.2015.12.010

Garcia-Herrero, A., \& Xu, J. (2019). How does China fare on the Russian market? Implications for the European Union. Russian Journal of Economics, 5 (4), 385-399. https://doi.org/10.32609/j. ruje.5.49346

GIEP (2018). Russian economy in 2017. Trends and outlooks. Moscow: Gaidar Institute for Economic Policy.

Gurvich, E., \& Prilepskiy, I. (2015). The impact of financial sanctions on the Russian economy. Russian Journal of Economics, 1 (4), 359-385. https://doi.org/10.1016/j.ruje.2016.02.002

IMF (2015). Russian Federation: Staff report for the 2015 Article IV Consultation. IMF Country Report, No. 15/211. Washington DC: International Monetary Fund.

IMF (2017a). Russian Federation. Selected issues. IMF Country Report, No. 17/198. Washington DC: International Monetary Fund.

IMF (2017b). Russia: Five reforms to increase productivity, diversify growth. IMF News, 10 July. https://www.imf.org/en/News/Articles/2017/07/05/na070717-russia-five-reforms-to-increaseproductivity-diversify-growth

Kholodilin, K. A., \& Netsunajev, A. (2016). Crimea and punishment: The impact of sanctions on Russian and European economies. DIW Berlin Discussion Papers, No. 1569. German Institute for Economic Research.

Korhonen, I., Simola, H., \& Solanko, L. (2018). Sanctions and countersanctions-effects on economy, trade and finance. Focus on European Economic Integration, Q3-2018, 68-76. Oesterreichische Nationalbank. Oesterreichische Nationalbank (Austrian Central Bank).

Kudrin, A., \& Knobel, A. (2018). Russian budget structure efficiency: Empirical study. Russian Journal of Economics, 4 (3), 197-214. https://doi.org/10.3897/j.ruje.4.30163

Kudrin, A., \& Sokolov, I. (2017). Fiscal maneuver and restructuring of the Russian economy. Russian Journal of Economics, 3 (3), 221-239. https://doi.org/10.1016/j.ruje.2017.09.001

Russell, M. (2016). Sanctions over Ukraine: Impact on Russia. European Parliamentary Research Service, Members' Research Service, PE 579.084. Available at http://www.europarl.europa.eu/ RegData/etudes/BRIE/2016/579084/EPRS_BRI(2016)579084_EN.pdf

Solow, R. M. (1956). A contribution to the theory of economic growth. Quarterly Journal of Economics, 70 (1), 65-94. https://doi.org/10.2307/1884513

Vishnevsky, A., \& Scherbakova, E. (2018). A new stage of demographic change: A warning for economists. Russian Journal of Economics, 4 (3), 229-248. https://doi.org/10.3897/j.ruje.4.30166

Volchkova, N., Kuznetsova, P., \& Turdyeva, N. (2018). Losers and winners of Russian countersanctions: A welfare analysis. Free Network Policy Brief Series, October1. Available at https://freepolicybriefs.org/2018/10/01/losers-and-winners-of-russian-countersanctions-awelfare-analysis/

Voskoboynikov, I. B. (2017). Sources of long run economic growth in Russia before and after the global financial crisis. Russian Journal of Economics, 3 (4), 348-365. https://doi.org/10.1016/j. ruje.2017.12.003

World Bank (2016). Russia economic report: The long journey to recovery (No. 35). Moscow: The World Bank in the Russian Federation. 